\title{
FIRST WORM-EATING WARBLER FOR SASKATCHEWAN
}

MURIEL GALLOWAY, 1168 Spadina Crescent East, Saskatoon, Saskatchewan S7K $3 \mathrm{H} 8$.

On 19 May 1979, a Worm-eating Warbler was seen in Saskatoon. This is the first recorded in Saskatchewan and probably the first for western Canada. Identification was certain by the four people who saw it: Mary Houston, Jim Slimmon, Geoff Galloway and the writer.

It was first seen scatching with both feet at once in leaf litter under shrubs. Later it was seen very clearly perched on a water bowl and photographed. It also searched for food in low shrubs and in wet soil along the fenceline. During the two hours, 1215 to 1415 , it was present in our yard and neighbouring yards it was not seen more than about two metres above the ground.

At one point Geoff Galloway saw it apparently catch something large on the ground and carry it a few centimetres into a young pine tree. It gulped twice but still had part of the food hanging from its bill. It looked like a robin eating a worm with difficulty. I looked through $8 \times 40$ binoculars and saw what seemed to be the distal end of an earthworm in the bill. The distance was 12 metres.

The interesting point here is that Worm-eating Warblers are rarely reported eating earthworms. Armyworms, other caterpillars and insects are the chief food. ${ }^{2}{ }^{14}$ The bird's scientific name translated means "wormeating worm-hunter," which is miseading.

\section{Description}

All four people who saw the Worm- eating Warbler agreed there was nothing else it could be. We were using various binoculars and Jim Slimmon had a small telescope. Books consulted at the time included Birds of Canada, ${ }^{6}$ Birds of North America ${ }^{12}$ and several field guides. ${ }^{489}$

There were no tail spots, wing bars or breast markings, just four longitudinal dark stripes on the head, the lower pair being through the eyes. The bill was pinkish brown and the feet were pink toning into pinkish brown legs. The back was a bright olivaceous buff, the wings browner, the sides were washed with a glowing russet buff; the head between the dark stripes was light olive buff; and the underparts were light yellowish buff. The total effect was of muted colour not drabness. It did not match any of the book plates in colour. Possibly it was in winter plumage. Ridgway ${ }^{10}$ says that adults in winter are more richly coloured and that legs and feet in dried skins are pale yellowish brown but more flesh coloured in life. This may account for the variety of leg and foot colours given in literature and plates. ${ }^{2} 361011$ Godfrey states that the bill is large for a warbler. The sexes are alike. ${ }^{2}{ }^{10}$

Because of the leaf-scratching behaviour, striped head and pinkish legs my initial reaction to the bird, before reaching for binoculars, was that it was a "small, wrongly-coloured White-crowned Sparrow"! It looked only a little smaller than a nearby Ovenbird and was possibly about 12 


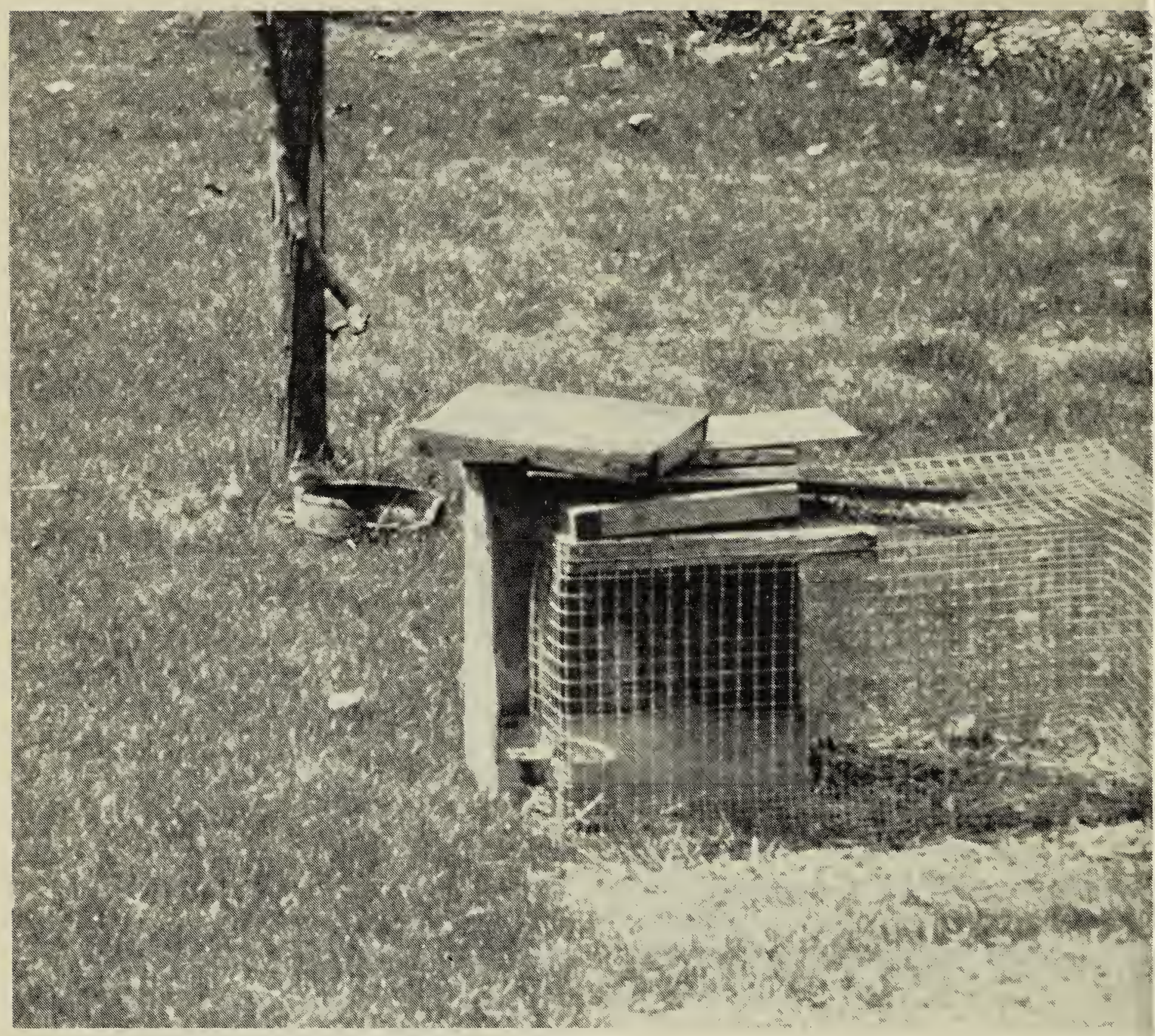

Worm-eating Warbler on waterbowl, 19 May 79

Geoff Galloway

$\mathrm{cm}$ long.

This unusual visitor was not heard singing. Its song resembles a Chipping Sparrow.

\section{Distribution}

There do not appear to be any records of its coming so far west and north before. Godfrey lists it as a casual spring visitor to Canada in extreme southern Ontario (in 1908; 1960; banded 1961). ${ }^{6}$ It is not listed in the Blue Jay Index 1961-19697 nor 1970-1978, (in preparation; pers. comm. from Mary Houston). The A.O.U. Checklist (1957) gives this warbler as casual in s. Ontario with no other mention of Canada. ${ }^{1}$

Peterson's Western Field Guide gives it only two lines in his section on accidental and marginal species. ${ }^{8}$ However, in his eastern guide the breeding range is given as "Connecticut to $\mathrm{n}$. Illinois ... s. to $\mathrm{n}$. Georgia and Missouri with Central America and the West Indies as wintering areas." "The breeding range is extended more recently west to eastern Kansas and Texas ${ }^{211}$ and possibly southern Nebraska. ${ }^{2}$ It is a casual spring migrant (nine records) in Minnesota ${ }^{5}$ where there is also one fall record for 1974 .

Was this a rare visitor or could the 
Worm-eating Warbler be extending its range to the northwest? Do any readers know of recent unpublished records from the Dakotas?

\section{Speculations}

An inconspicuous ground-nesting warbler with a song strongly resembling the Chipping Sparrow could go unnoticed, especially if it occurred outside its normal range. It would take a really alert birder's ear in late May or June to pinpoint birds on territory and see them. He would also need to wonder why the familiar wood-edge, city-shade-tree chippy was out of its habitat and in low hillside shrubs and brush. Apparently the warbler is often silent in July and early August during the moult, but sings in late August and early September.

It is a bird with preferences for rocky and shrubby hillsides, watercourses and young deciduous saplings. ${ }^{2}$ So it may be no coincidence that the city yard where it was found, after rain, is close to the South Saskatchewan River and has deciduous scrub around the edges. It is usually visited by Ovenbirds and Northern Waterthrushes on migration.

\section{Conclusion}

An immigrant naturalist like myself has few preconceived ideas about the limitations on likely species because so much is new to the observer anyway. Consequently I was pleased that established birders Mary Houston (with a flat tire) and Jim Slimmon (without lunch) were able to come and confirm this sighting before the bird eft. Also I am very grateful to Bernie Gollop for making reference material available to me and ensuring that the account was written up while freshly emembered.

What I find hard to believe is that this was the only individual of the species that migrated into Saskatchewan this year. Perhaps there is a case for Saskatchewan birders actively to look and listen for Wormeating Warblers, especially in Spring.

'AMERICAN ORNITHOLOGISTS' UNION. 1957. Check-list of North American birds. 5 th ed. American Ornithologists' Union. $691 \mathrm{pp}$.

2BENT, A.C. 1963 (copy of 1953). Life histories of North American wood warblers. Part 1. Dover, New York. $367 \mathrm{pp}$.

${ }^{3}$ BULL, J. and J. FARRAND. 1977. The Audubon Society field guide to North American birds. Eastern region. Knopf, New York. 775 pp.

${ }^{4}$ COLLINS, H.H. 1959. Complete field guide to American wildlife: east, central and north. Harper \& Row, New York. $683 \mathrm{pp}$.

${ }^{5}$ GREEN, J.C. and R.B. JANSSEN. 1975. Minnesota birds. Univ. of Minnesota Press. 217 pp.

${ }^{6}$ GODFREY, W.E. 1966. Birds of Canada. Nat. Mus. Can. Bull. 203. Ottawa. 428 $\mathrm{pp}$.

'O'NEIL, P. 1975. Blue Jay index 19611969. S.N.H.S. Spec. Publ. 8.

${ }^{8}$ PETERSON, R.T. 1941. A field guide to western birds. Houghton Mifflin, Boston. $366 \mathrm{pp}$.

${ }^{9}$ PETERSON, R.T. 1947. A field guide to the birds. Houghton Mifflin, Boston. $230 \mathrm{pp}$.

${ }^{10}$ RIDGWAY, R. 1902. The birds of North and Middle America. Part 2. Govt. Printing Office, Washington. $834 \mathrm{pp}$.

"REILLY, E.M. 1968. The Audubon illustrated handbook of American birds. McGraw Hill, New York. 524 pp.

${ }^{12}$ ROBBINS, C.S., B. BRUNN, H.S. ZIM. 1966. Birds of North America. Golden Press, New York. 340 pp.

${ }^{13}$ SAUNDERS, A.A. 1951. A guide to bird songs. Doubleday, New York. 307 pp.

${ }^{14}$ SPRUNT, A. 1957. Pages 55-58 In GRISCOM, L., A. SPRUNT. The warblers of North America. DevinAdair Co., New York. 365 pp. 